\title{
Under the influence of regulations: spatio-temporal trends of the UV filter 2-Ethylhexyl-4-methoxycinnamate (EHMC) in German rivers
}

Regine Nagorka* (1D and Anja Duffek

\begin{abstract}
Background: Globally, 2-Ethylhexyl-4-methoxycinnamate (EHMC) is one of the most commonly used UV filters in sunscreen and personal care products. Due to its widespread usage, the occurrence of EHMC in the aquatic environment has frequently been documented. In the EU, EHMC is listed under the European Community Rolling Action Plan (CoRAP) as suspected to be persistent, bioaccumulative, and toxic (PBT) and as a potential endocrine disruptor. It was included in the first watch list under the Water Framework Directive (WFD) referring to a sediment PNEC of $200 \mu \mathrm{g} /$ $\mathrm{kg}$ dry weight (dw). In the light of the ongoing substance evaluation to refine the environmental risk assessment, the objective of this study was to obtain spatio-temporal trends for EHMC in freshwater.

We analyzed samples of suspended particulate matter (SPM) retrieved from the German environmental specimen bank (ESB). The samples covered 13 sampling sites from major German rivers, including Rhine, Elbe, and Danube, and have been collected since mid-2000s.

Results: Our results show decreasing concentrations of EHMC in annual SPM samples during the studied period. In the mid-2000s, the levels for EHMC ranged between 3.3 and $72 \mathrm{ng} / \mathrm{g} \mathrm{dw}$. The highest burden could be found in the Rhine tributary Saar. In 2017, we observed a maximum concentration ten times lower $(7.9 \mathrm{ng} / \mathrm{g}$ dw in samples from the Saar). In $62 \%$ of all samples taken in 2017 , concentrations were even below the limit of quantification (LOQ) of $2.7 \mathrm{ng} / \mathrm{g} \mathrm{dw}$.

Conclusions: The results indicate a general declining discharge of EHMC into German rivers within the last 15 years and correspond to the market data. Although the measured levels are below the predicted no-effect level (PNEC) in sediment, further research should identify local and seasonal level of exposure, e.g., at highly frequented bathing waters especially in lakes. In addition, possible substitutes as well as their potentially synergistic effects together with other UV filters should be investigated.
\end{abstract}

Keywords: UV filter, EHMC, Environmental trend monitoring, Major German river basins, Suspended particulate matter, Water Framework Directive

*Correspondence: regine.nagorka@uba.de

Department "Water and Soil", Laboratory for Water Analysis, German Environment Agency (Umweltbundesamt), Corrensplatz 1, 14195 Berlin, Germany

\section{Background}

EHMC (2-Ethylhexyl-4-methoxycinnamate), also known as octinoxate, is one of the most popular organic UV filters used in sunscreens. EHMC as an isomer mixture consists mainly of more than $80 \%$ of the trans-isomer (2-Ethylhexyl trans-4-methoxycinnamate, EC no.: 629661-9, CAS no.: 83834-59-7) and has been registered 
under REACH as 2-Ethylhexyl 4-methoxycinnamate before 2013 (EC no.: 226-775-7, CAS no.: 5466-77-3). Both isomers further include the R- and S-enantiomers. Therefore, EHMC may refer to a composition containing four constituents. As an UVB filter, EHMC is authorized by the European cosmetics regulation [1] for use in cosmetics up to $10 \%$. In order to achieve complete protection against both UVB and UVA radiations, EHMC is commonly combined with other UV filters in sunscreen products according to the recommendations given by the European Commission in 2006 [2]. Apart from its application as a sunscreen, EHMC is increasingly used as an UV absorber to prevent a variety of personal care, washing and cleaning products against photodegradation [3, 4].

EHMC has a $\log \mathrm{K}_{\mathrm{OW}}>5.8[3,5]$, so adsorbing to solids would be expected. Although the compound is slightly soluble in water [6], it has been widely detected in fresh and sea water up to $4043 \mathrm{ng} / \mathrm{l}$ [7-11]. A seasonal pattern with higher concentrations during the summer month was observed at beaching sites [12]. EHMC is lipophilic and accumulates in biota showing a tendency to bioaccumulate through different trophic levels [13].

The substance is not persistent in the environment as it is readily biodegradable and also degradable under anaerobic conditions. EHMC is unstable in sunlight and can be transformed from trans-EHMC to emergent cisEHMC which showed a greater risk to genotoxic effects than the trans-isomer [14]. Endocrine-disrupting potential of EHMC has been suggested in several in vitro and in vivo studies [15-20]. In addition, thyroid-disrupting effects of EHMC are suggested in experimental studies [21-24]. EHMC has demonstrated multiple hormone activities in fish with gene expression profiling showing antiestrogenic activity [18]. Recently it has been reported that EHMC may affect reproduction and thyroid hormonal balance of fish [25].

The broad use in large amounts is associated with its occurrence in the environment and humans, which has raised significant concerns about the safety of EHMC. The concerns as regards environmental aspects are taken care under the REACH regulation, where EHMC is registered as the so-called existing substance supplied in the EU since decades at high tonnage between 1000 and $10,000 \mathrm{t} / \mathrm{a}$. According to ECHA, the structural similar substances 2-Ethylhexyl trans-4-methoxycinnamate and 2-Ethylhexyl 4-methoxycinnamate may be jointly evaluated for environmental risks. EHMC has been included into the CoRAP list 2014 for further evaluation as suspected PBT and its potential for endocrine activity in amphibians and fish [26, 27]. As part of the evaluation, emissions will be assessed with regard to risk to the aquatic environment. On this basis, EHMC was placed on the European watch list of substances that may pose a significant risk to the aquatic environment [28]. Monitoring in sediment or SPM had been recommended for this lipophilic substance. In 2018, it was decided to remove EHMC from the watch list and to consider its re-inclusion to the third watch list. But again in 2020, EHMC has not be included into the revised surface water watch list due to concerns about EU-wide comparable sediment monitoring $[29,30]$.

The present study is part of a project in order to provide information of emerging contaminants, which are under regulatory pressure, e.g., plasticizers [31]. This paper aims to investigate spatial patterns and retrospective temporal trends of EHMC in freshwater systems and intends to support the watch list mechanism. We analyzed archived SPM samples from the German environmental specimen bank (ESB) for the mixture of cis- and trans-isomers. The samples were collected between the mid-2000s and 2017 from the major German river basins, like Rhine, Danube, Elbe, and their tributaries. Another purpose of this study was to evaluate whether EHMC levels in the environment were already affected by regulatory processes. For our best knowledge, this is the first long-term monitoring. Such retrospective monitoring with archived ESB samples allows trend assessment for EHMC.

\section{Methods}

\section{Selection of samples from the ESB}

Here we give a brief description of sample collection and preparation and the analytical method. Details can be found in the references cited and in Supporting Information (SI). The extensive sampling and archiving program of the ESB includes inter alia SPM sampling in large German Federal waterways. Since 2005, SPM samples are taken at nine sites in the Rhine (R1, R3, and R4) and Elbe (E1, E2, E4, and E5) river basins and the Elbe tributaries Saale (Sa) and Mulde (Mu). Two sites in the Saar (S1 and S2) and two sites in the Danube (D1 and D3) are sampled since 2006 and 2009, respectively [32]. A short characterization of the sampling sites is given in Additional File 1: Table S1 (adapted from [33]).

Suspended particles are collected in sedimentation boxes and sampled on a monthly basis. 12 monthly samples are than pooled to one annual sample. The samples are sieved $(<2 \mathrm{~mm})$, homogenized, and freeze-dried [34].

In total, 73 samples were analyzed. For each site EHMC levels were determined for the first sampling year and for 2017. Time trends between 2005 (2006 for the Saar site) and 2017 were studied at eight sites (E1, E2, E4, Sa, R1, R3, R4, and S2) by analyzing samples from every second year of the annual ESB sampling program. Details on 
sampling frequency and the number of samples for each site are listed in Additional File 1: Table S2.

\section{Chemicals and materials}

EHMC was purchased from Sigma-Aldrich. EHMC has been analyzed together with other emerging substances, such as plasticizers and fragrances. In order to cover a broad retention range, four deuterated phthalates were used for quantification. One of them, d4-Dihexyl phthalate (d4-DHP) was selected as deuterated internal standard (IS) for EHMC analysis and was also purchased from Sigma-Aldrich. The suitability of d4-DHP for quantification of EHMC had been previously tested on the basis of chromatographic behavior, response factor, and similar behavior during the sample treatment process (recovery rates). Stock solutions and working solutions of EHMC and the labeled standard were prepared in acetonitrile and stored at $5{ }^{\circ} \mathrm{C}$. Further information on chemicals and materials is available in SI. Chemical and physical properties of EHMC are described in Additional File 1: Table S3.

\section{Extraction and clean-up}

The method has already been presented [31] and is only briefly described here. Before extraction, the deuterated phthalate d4-DHP was added to the aliquots of the freeze-dried SPM sample. Extraction was performed in an ultrasonic bath using two times acetone/ dichloromethane/n-hexane followed by an n-hexane/ acetone mixture (each for $10 \mathrm{~min}$ ). The combined extracts were concentrated to approximately $0.5 \mathrm{ml}$ in a $\mathrm{N}_{2}$ stream. Samples were cleaned up on a Florisil column with ethyl acetate/acetonitrile/dichloromethane. The eluate was concentrated in a $\mathrm{N}_{2}$ stream to approximately $0.5 \mathrm{ml}$ and reconstituted in acetonitrile for analysis. Details of the extraction and clean-up procedure are described in SI.

\section{LC-MS/MS analysis}

Analysis was performed by liquid chromatographymass spectrometry analysis (LC-MS/MS), using an Agilent 1290 infinity II LC combined with an SCIEX QTRAP $6500+$ MS. LC-MS/MS operation parameters are presented in SI. EHMC was quantified using d4-DHP as IS, which was added prior to extraction (for details see Additional File 1: Tables S4 and S5).

\section{Quality assurance}

Pretreatment of the laboratory tools to avoid contamination is described in SI. As mentioned above, the investigation of EHMC in SPM samples was part of a study including also plasticizers in the analyte spectrum. The analysis of plasticizers, especially of phthalates, is notorious for blank problems. Hence, the quality assurance procedures and standards were adapted to this problematic substance group. Method blanks were prepared to check possible contamination during the complete sample treatment. Additionally, a blank check of each clean-up column was carried out prior to use. Concentrations of the analyte in samples were quantified using d4-DHP as IS after the mean blank values (average value of a preparation sequence, $n=4-5$ ) have been subtracted. The limit of detection (LOD) and the limit of quantification (LOQ) were estimated by measuring replicates $(n=10)$ of method blank values. LOD and LOQ were calculated by using the standard deviation $\left(\mathrm{SD}_{\text {blank }}\right)$ of the blanks ( $\mathrm{LOD}=3 * \mathrm{SD}_{\text {blank }}$ and $\left.\mathrm{LOQ}=9 * \mathrm{SD}_{\text {blank }}\right)$. For EHMC the LOQ was $2.7 \mathrm{ng} / \mathrm{g} \mathrm{dw}$ (the LOD value is given in SI). The validation of the analytical method for the UV filter was assessed through spikes of the analytes to aliquots (about $1 \mathrm{~g}$ ) of a pooled SPM sample. The pooled SPM sample was obtained by mixing already extracted SPM samples, which were dried before pooling. The spiked samples followed the same procedure as the other samples in this study. Recovery rates of $94 \%$ and $104 \%$, respectively, ( $n=5$ for each of the two concentration levels $102 \mathrm{ng} / \mathrm{g} \mathrm{dw}$ and $255 \mathrm{ng} / \mathrm{g} \mathrm{dw}$ investigated) were obtained with a relative standard deviation of about 2.4\% (see Additional File 1: Table S7). The repeatability was calculated as the relative standard deviation (RSD) of five replicate measurements of the same SPM sample under repeatable conditions. RSD values were $5-25 \%$ for EHMC.

\section{Statistical analyses}

In multiple analyses of the same SPM sample $(n=2-5)$, a geometric mean value (GM) was determined from the individual values. Values below LOQ were taken into account with half of LOQ.

For trend analysis, a software tool from the German Environment Agency was applied (LOESS-Trend, Version 1.1, based on Microsoft Excel). This tool fits a locally weighted scatterplot smoother (LOESS; fixed window width of seven years) through the yearly contaminant levels and then tests for significance of linear and nonlinear trend components by means of an Analysis of Variance (ANOVA) [35].

\section{Results and discussion \\ Spatial and temporal comparison of EHMC levels in riverine SPM in the mid-2000s and 2017}

Figure 1 shows the levels of EHMC in SPM from six German rivers at sampling sites in the respective first year of sampling in 2005, 2006, and 2009 in comparison to the last investigation in 2017. Detection frequencies are given in SI (Additional File 1: Table S8a). We found 


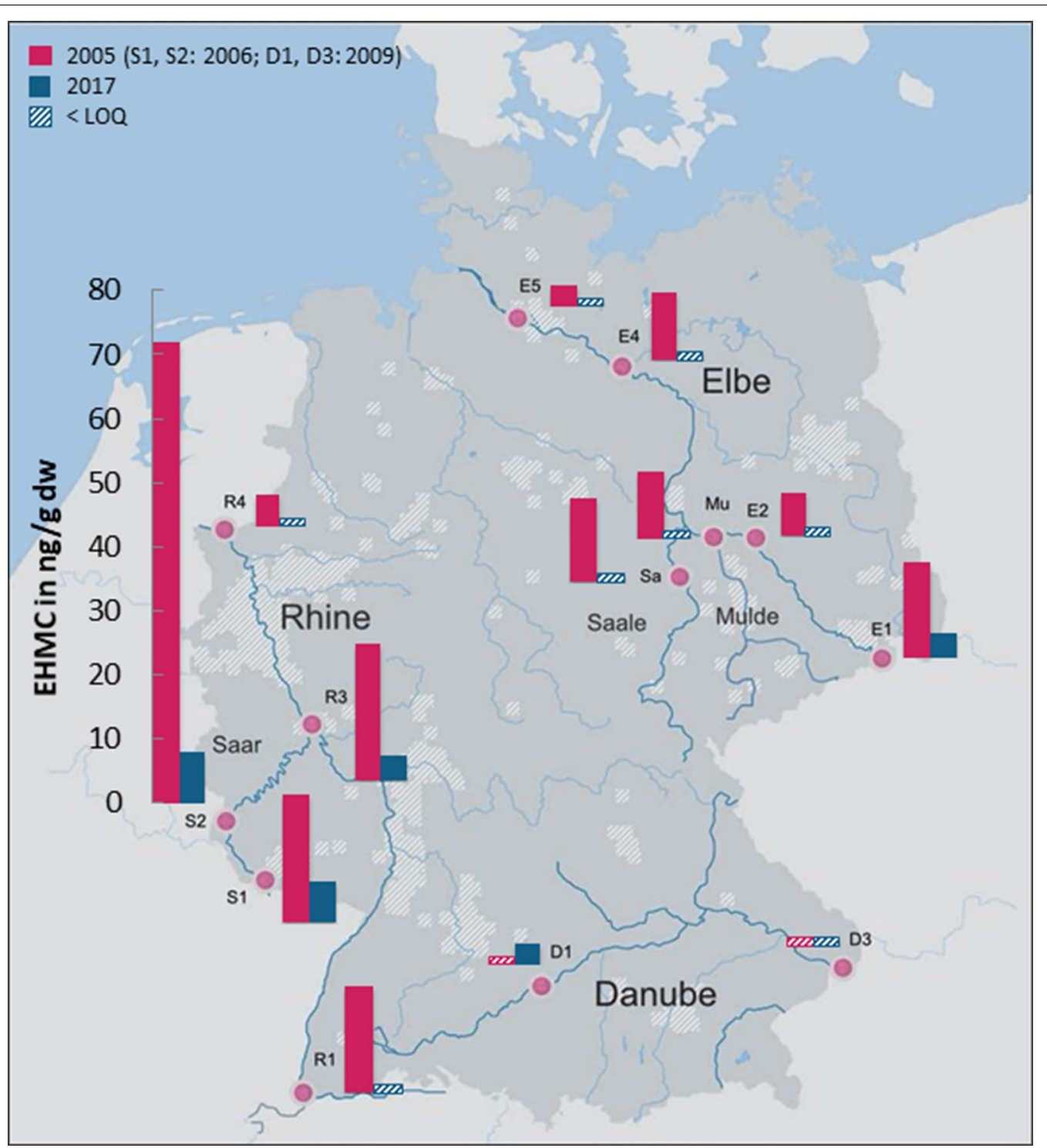

Fig. 1 EHMC in SPM samples from German rivers (concentration in $\mathrm{ng} / \mathrm{g} \mathrm{dw}$ ). Measured value $<L O Q$ of $2.7 \mathrm{ng} / \mathrm{g}$ dw has been set to half of $L O Q$

significant differences for EHMC between the individual locations. In the mid-2000s, at 11 sites in the rivers Rhine, Elbe, Saale, Mulde, and Saar, the EHMC concentrations ranged from $3.3 \mathrm{ng} / \mathrm{g} \mathrm{dw}$ (E5, downstream Elbe) to $72 \mathrm{ng} / \mathrm{g} \mathrm{dw}$ (S2, Saar), which is about a factor of 20 . In 2017, the detection frequency (\% $\geq$ LOD) for $\mathrm{EHMC}$ was $100 \%$ at these sites, but the levels had decreased significantly compared to 2005/06. The maximum level was also measured in the sample of the Saar river $(\mathrm{S} 2,7.9 \mathrm{ng} / \mathrm{g} \mathrm{dw})$, but was 10 times lower than it was in the mid-2000s. For the E1, R3, and S1 sites, the levels had decreased to $20-30 \%$ of the first measured value. At seven sites (E2, E4, E5, Mu, Sa, R1, and R4) we found concentrations below LOQ.

The EHMC concentrations at the Danube sites D1 and D3 were below LOQ in 2009 and at D3 in 2017. In the sample taken in 2017 from D1, a value of $3.3 \mathrm{ng} / \mathrm{g} \mathrm{dw}$ was measured.

In order to reduce the inherent variability of SPM samples, concentrations have been normalized to the total organic carbon (TOC) content in the first year of sampling and in 2017 (TOC contents and normalized LOQs for the individual sites are given in Additional File 1: Table S6a-b; the normalized concentrations are listed 


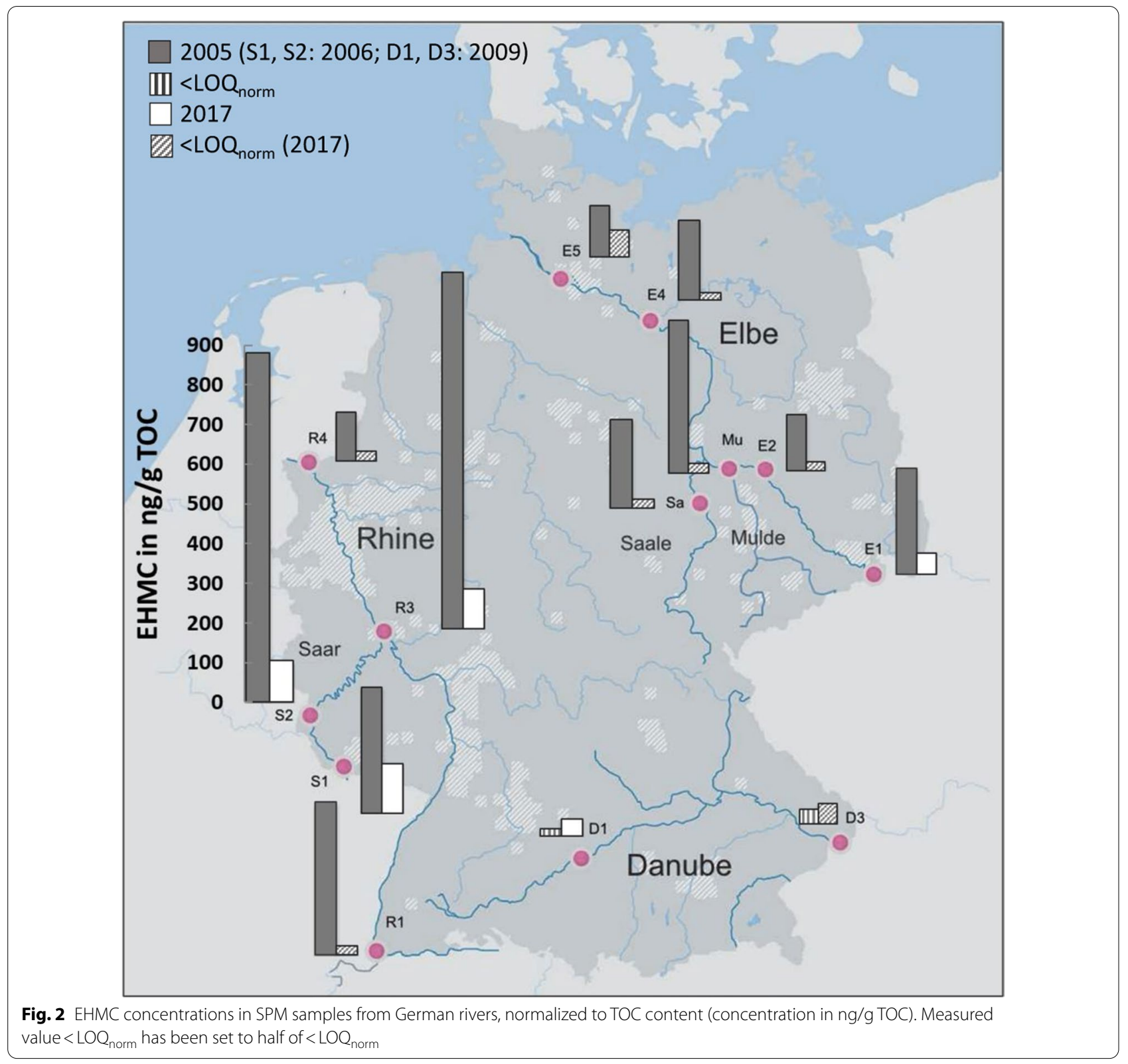

in Additional File 1: Table S8b). As shown in Fig. 2, the normalization underlines the high values in Rhine (R3, $891 \mathrm{ng} / \mathrm{g}$ TOC in 2005) and Saar (S2, $881 \mathrm{ng} / \mathrm{g}$ TOC in 2006). Although, there are smaller differences between the individual sites compared to the absolute values, a similar spatial and temporal pattern could be observed after normalization. An exception is the normalized concentration in R3 from 2005, which is about twice as high as in $\mathrm{R} 1$ (448 $\mathrm{ng} / \mathrm{g}$ TOC). This is in contrast to the absolute values (R1, $17 \mathrm{ng} / \mathrm{g} \mathrm{dw}$; $33,21 \mathrm{ng} / \mathrm{g} \mathrm{dw}$ ).

The Rhine is the river with the highest water discharge in Germany. Its average volume of water doubles between
R1 and R3 from $1000 \mathrm{~m}^{3} / \mathrm{s}$ to approximately $2000 \mathrm{~m}^{3} / \mathrm{s}$ $[36,37]$, mainly due to the confluence of the major tributaries Main and Neckar. Despite the higher dilution potential, we found increasing EHMC levels between R1 and R3 in the mid-2000s and to a lesser extent in 2017. A major pollution source may be attributed to a production site of UV filters (including EHMC) located upstream of R3. Additionally, the discharge of Main and Neckar can contain more than $30 \%$ and $50 \%$, respectively, of wastewater treatment plant effluents at their confluence with the Rhine [38]. From R3 downstream to R4, the EHMC level decreased and low concentrations were observed 
at the site R4 (2005: $5.0 \mathrm{ng} / \mathrm{g} \mathrm{dw}$ and 2017:<LOQ). The TOC-normalized levels from 2005 underline the concentration pattern in the longitudinal profile of the Rhine (see Fig. 2).

Maximum values were detected in SPM samples from the two Saar sites, particularly at S2. This may be originated by urban impact. S2 is located downstream from the cities of Saarbrücken and Saarlouis. The water volume of Saar is low [39] and in the investigated river section, wastewater treatment plant effluents can reach up to $50 \%$ of the water discharge [38].

An impact of urban and industrial wastewater discharge on EHMC levels in surface water systems was also observed in other studies. Removal rates for EHMC in wastewater treatment plants reported in the literature ranged from 40 to $100 \%$ [8, 40-42]. Although the hydrophobic UV filter is mainly found in sewage sludge [43], EHMC has been detected in effluent water with contents up to $849 \mathrm{ng} / \mathrm{l}[44,45]$, in effluent sediment [8] and directly downstream from the effluent point $[46,47]$. Kameda et al. found in the sediment of heavily polluted rivers up to $30 \mathrm{ng} \mathrm{EHMC} / \mathrm{g} \mathrm{dw}$, whereas only up to $8 \mathrm{ng} / \mathrm{g}$ $\mathrm{dw}$ were detectable in the sediment of background sites [8].

The EHMC levels found in this study are in line with those found in other investigations in sediment or SPM samples in Europe (see Table 1). The overall data indicate a decreasing contamination in European surface waters. Since the mid-2010s, mean and median values were mainly below LOQ. In contrast to previous studies, the frequency for EHMC values $\geq$ LOQ ranged between 0 and $38 \%$ and EHMC was only detected in low concentrations.

\section{Temporal trends of EHMC}

To identify temporal trends, SPM samples from eight sampling sites (E1, E2, E4, Sa, R1, R3, R4, and S2) were analyzed at intervals of one to two years (sampling interval see Additional File 1: Table S2). The temporal course of concentrations for EHMC in SPM from eight sampling sites between 2005 (2006 in S2) and 2017 are presented in Fig. 3a-h. EHMC levels decreased significantly $(p<0.05)$ in SPM samples from all sites, in particular before 2008.

For EHMC concentrations, Additional File 1: Fig. S1a shows the results of the linear trend analysis, given as the average annual decline. The results of the linear trend analysis based on TOC-normalized values are illustrated in Additional File 1: Fig. S1b.

The maximum decline rate was observed in samples from S2 with annual decreases of $5.2 \mathrm{ng} / \mathrm{g} \mathrm{dw}$ and $62 \mathrm{ng} / \mathrm{g}$ TOC, respectively. At the sampling site with the highest TOC-normalized level in 2005 (R3), we found a lower rate of decrease of $40 \mathrm{ng} / \mathrm{g}$ TOC per annum.

Our findings are in accordance with the EU market data. For EHMC the frequency of use strongly decreased. In 1998, EHMC was an ingredient in more than 50\% of the sunscreens investigated [11]. A study in Denmark in 2002 showed similar results (49\%) [56]. Since the mid-2010s, shares of EHMC-containing sunscreen products of $1.5-17 \%$ were reported [57-61]. This development could be related to the fact that REACH has been adopted in 2006, whereupon, EHMC has been registered

Table 1 Overview on reported EHMC concentrations in European SPM samples and sediment (concentration unit: ng/g dw)

\begin{tabular}{|c|c|c|c|c|c|c|c|c|}
\hline Sampling location & Sampling year & Matrix & LOQ & $\% \geq \mathrm{LOQ}$ & Range & Median & Mean & Study \\
\hline Germany, main rivers and tributaries & 2005/06 & SPM & 2.7 & 100 & $3.3-72$ & 13 & 18 & our study \\
\hline Germany, lakes near Leipzig & 2007 & sediment & $5^{\mathrm{a}}$ & $100^{b}$ & $14-34$ & n. $a^{c}$ & n. $a^{c}$ & {$[48]$} \\
\hline Spain, Ebro river basin & 2009 & sediment & 5.3 & 15 & $<$ LOQ-42 & $<\mathrm{LOQ}$ & 6 & {$[49]$} \\
\hline Spain, Andulusian coast & 2012 & sediment & 0.129 & 83 & $<\mathrm{LOQ}-26.2$ & 12.8 & 13.1 & {$[50]$} \\
\hline Norway, Oslofjord and Lake Mjøsa & 2013 & sediment & $\mathrm{n} \cdot \mathrm{a}^{\mathrm{c}}$ & $100^{b}$ & $8-20$ & 11 & 13 & {$[51]$} \\
\hline $\begin{array}{l}\text { Sweden, Uppsala WWTP effluent, bath- } \\
\text { ing lakes in South Sweden }\end{array}$ & 2014 & sediment & 7 & 38 & $<$ LOQ-35 & $<\mathrm{LOQ}$ & 10 & {$[46]$} \\
\hline Spain, Catalan rivers & 2014 & SPM & 6.5 & 0 & $<\mathrm{LOQ}$ & $<\mathrm{LOQ}$ & $<\mathrm{LOQ}$ & {$[42]$} \\
\hline Italy, Adriatic Sea & 2014 & sediment & 0.129 & 100 & $0.7-10.4$ & 2.9 & 3.3 & {$[52]$} \\
\hline Greece, Evrotas river & $2014 / 15$ & sediment & 0.2 & 0 & $<\mathrm{LOQ}$ & $<\mathrm{LOQ}$ & $<\mathrm{LOQ}$ & [53] \\
\hline Italy, Alpin rivers & 2015 & sediment & 0.1 & 0 & $<\mathrm{LOQ}$ & $<\mathrm{LOQ}$ & $<\mathrm{LOQ}$ & {$[54]$} \\
\hline $\begin{array}{l}\text { Germany, German Bight, Baltic Sea, } \\
\text { Skagerrak and Kattegat }\end{array}$ & 2015/17 & sediment & 0.25 & 7 & $<$ LOQ-0.32 & $<\mathrm{LOQ}$ & $<\mathrm{LOQ}$ & {$[55]$} \\
\hline Germany, main rivers and tributaries & 2017 & SPM & 2.7 & 38 & $<\mathrm{LOQ}-7.9$ & $<\mathrm{LOQ}$ & 2.9 & our study \\
\hline
\end{tabular}

\footnotetext{
a $L O D$ (LOQ value is not reported)

b $100 \% \geq L O D$ (information given by the reference)

c n.a, value not available
} 


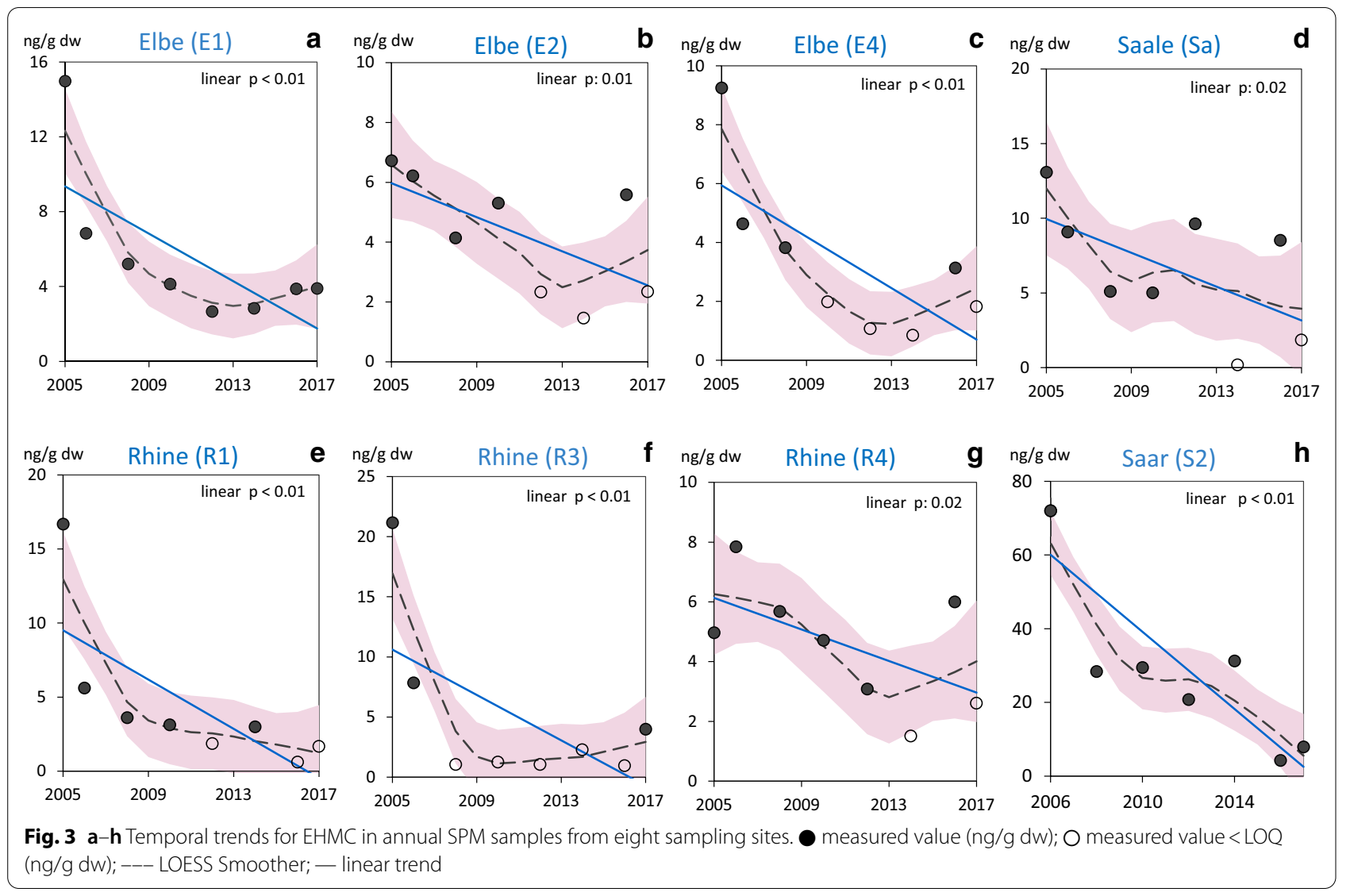

in 2010, evaluated in 2013, and listed on the CoRAP list in 2014 because of insufficient information on environmental risks. Furthermore, in the beginning of the 2000s, there was a growing awareness of additional damage caused by UVA radiation. As a consequence, UVA and broadband filter had been increasingly available on the EU market $[62,63]$.

\section{Regulatory assessment of the exposure data}

The concentrations found in time-integrated samples of suspended particulate matter give no rise of concern as all levels determined and especially the actual levels of less than $0.01 \mathrm{mg} / \mathrm{kg} \mathrm{dw}$ are far below the PNEC in sediment of $0.2 \mathrm{mg} / \mathrm{kg} \mathrm{dw}[28,64]$. This appears to indicate that EHMC contamination may not be of concern for the studied aquatic environment. We have to point out that the samples of suspended particulate matter represent annual average composites of monthly taken samples at equal proportions. Therefore, our study gives a general view on spatial and annual variations from a retrospective view and does not address possibly occurring local higher short-term concentrations.

\section{Conclusions}

Our study indicates a decreasing discharge of EHMC into German waters within the last 15 years. This might be attributed to a decreasing use as well as a changing usage pattern in conjunction with improved wastewater treatment. Although the frequency of use as an ingredient in sunscreens in Germany strongly decreased from about $65 \%$ in 1994 to $15 \%$ in 2014 , EHMC is still one of the most important UVB filters in daily care products [58]. EHMC frequently occurs in lip or skin care products and face creams in about $30 \%$ up to $75 \%$ [57-59]. Therefore, indirect and continuous discharge in freshwater systems via urban wastewater cannot be excluded and might be related to the current levels in highly industrialized and densely populated areas. Our data in support of the ongoing environmental exposure assessment [65] underline the need of a targeted sediment monitoring and serve as a starting point for designing future monitoring programs. Thereby, possible occurrence and changing use patterns of EHMC should to be taken into account as required for the watch list monitoring. Nevertheless, the occurrence of possible substitutes, other UV filters and their potentially synergistically effects should be critically investigated in 
further studies. Among the new developments are the use of inorganic nanoparticles [66] and high-molecular weight compounds, like triazine derivatives [58]. Recent studies already documented the upcoming presence of Ethylhexyl triazone (EHT) and Bis-ethylhexyloxyphenol methoxyphenyl triazine (BEMT) in the aquatic environment [55, 67]. The growing demand of UV filters and current increases in production [68] may cause a higher pollution of water bodies with these novel compounds.

\section{Supplementary Information}

The online version contains supplementary material available at https://doi. org/10.1186/s12302-020-00448-w.

Additional File1: Table S1 Sampling sites of the ESB. Table S2 Sampling and measurement period between 2005 and 2017. Table S3 General information on EHMC. Table S4 Information on LC-MS/MS system and parameters. Table S5 Information on substance specific parameters for EHMC detected by LC-MS/MS. Table S6a TOC contents in SPM samples at the sampling sites between 2005 and 2017 [6] (in $\mu \mathrm{g} / \mathrm{g}$ ). Table S6b LOQnorm values at the sampling sites between 2005 and 2017 (in ng/g TOC). Table S7 Recoveries for EHMC at two different concentration levels. Table S8a Concentrations of EHMC in SPM samples at the sampling sites (in ng/g dw). Table S8b TOC-normalized concentrations of EHMC in SPM samples at the sampling sites (in ng/g TOC). Fig S1 Average annual change in EHMC concentrations resp. in EHMC concentrations normalized to TOC between 2005 (resp. 2006 at S2) and 2017 (significant linear regression; $p<0.05)($ PDF 408 KB)

\section{Abbreviations}

EHMC: 2-Ethylhexyl-4-methoxycinnamate; UV filter: Ultraviolet filter; EU: European Union; CoRAP: Community Rolling Action Plan; PBT: Persistent, bioaccumulative, and toxic; WFD: Water Framework Directive; dw: dry weight; SPM: Suspended particulate matter; ESB: German environmental specimen bank; LOQ: Limit of quantification; PNEC: Predicted no-effect concentration; d4-DHP: D4-Dihexyl phthalate; IS: Internal standard; LC-MS/MS: Liquid chromatography mass spectrometry analysis; LOD: Limit of detection; RSD: Relative standard deviation; GM: Geometric mean value; ANOVA: Analysis of Variance; TOC: Total organic carbon.

\section{Acknowledgements}

The authors wish to express their gratitude to Lydia Windmüller, Stefan Clausius, and Lara Bräuer for technical support and Jörg Wellmitz for providing the LOESS software tool by the German Environment Agency. They thank the ESB project partners at Fraunhofer IME and BfG for sampling, preparation, and cryo-archiving of the SPM samples.

\section{Authors' contributions}

$\mathrm{RN}$ was involved in the experiments. RN and AD designed the study and were involved in manuscript writing. Both authors read and approved the final manuscript.

\section{Funding}

Open Access funding enabled and organized by Projekt DEAL.

\section{Availability of data and materials}

All data generated or analyzed during this study are included in this published article and its additional information file.

Ethics approval and consent to participate

Not applicable.

Consent for publication

Not applicable.

\section{Competing interests}

The authors declare that they have no competing interests.

Received: 13 October 2020 Accepted: 18 December 2020

Published online: 14 January 2021

\section{References}

1. EC (European Commission) (2009) Regulation (EC) No 1223/2009 of the European Parliament of 30 November 2009 on cosmetic products. OJ L 342/59. https://ec.europa.eu/health/sites/health/files/endocrine_disru ptors/docs/cosmetic_1223_2009_regulation_en.pdf

2. EC (European Commission) (2006) Commission recommendation of 22 September 2006 of the efficacy of sunscreen products and the claims made relating thereto. OJ L 265/39. https://eur-lex.europa.eu/eli/ reco/2006/647/oj

3. ECHA (European Chemicals Agency) (2020) Registered Substances. Database on information on registered substances under REACH by search on CAS No. https://echa.europa.eu/de/substance-information/-/substancei nfo/100.157.824

4. Gago-Ferrero P, Mastroianni N, Díaz-Cruz MS, Barceló D (2013) Fully automated determination of nine ultraviolet filters and transformation products in natural waters and wastewaters by on-line solid phase extraction-liquid chromatography-tandem mass spectrometry. J Chromatogr A 1294:106-116. https://doi.org/10.1016/j.chroma.2013.04.037

5. EA (Environment Agency) (2008) UV filters in cosmetics-priorisation for environmental assessment. https://assets.publishing.service.gov.uk/gover nment/uploads/system/uploads/attachment_data/file/291007/scho1 008bpay-e-e.pdf

6. Ramos S, Honem V, Alves A, Santos L (2015) Advances in analytical methods and occurrence of organic UV filters in the environment-A review. Sci Total Environ 526:278-311. https://doi.org/10.1016/j.scito tenv.2015.04.055

7. Sánchez Rodríguez A, Rodrigo Sanz M, Betancort Rodríguez JR (2015) Occurrence of eight UV filters in beaches of Gran Canaria (Canary Islands). An approach to environmental risk assessment. Chemosphere 131:85-90. https://doi.org/10.1016/j.chemosphere.2015.02.054

8. Kameda Y, Kimura K, Miyazaki M (2011) Occurrence and profiles of organic sun-blocking agents in surface waters and sediments in Japanese rivers and lakes. Environ Pollut 159:1570-1576. https://doi. org/10.1016/j.envpol.2011.02.055

9. Tsui MMP, Leung HW, Wai T-C, Yamashita N, Taniyasu S, Liu W, Lam PKS, Murphy MB (2014) Occurrence, distribution and ecological risk assessment of multiple classes of UV filters in surface waters from different countries. Water Res 67:55-65. https://doi.org/10.1016/j.watre s.2014.09.013

10. Teijon G, Candela L, Tamoh K, Molina-Díaz A, Fernández-Alba AR (2010) Occurrence of emerging contaminants, priority substances (2008/105/ CE) and heavy metals in treated wastewater and groundwater at Depurbaix facility (Barcelona, Spain). Sci Total Environ 408:3584-3595. https:// doi.org/10.1016/j.scitotenv.2010.04.041

11. Poiger T, Buser HR, Balmer ME, Bergqvist PA, Müller MD (2004) Occurrence of UV filter compounds from sunscreens in surface water: regional mass balance in two Swiss lakes. Chemosphere 55:951-963. https://doi. org/10.1016/j.chemosphere.2004.01.012

12. Tashiro Y, Kameda Y (2013) Concentration of organic sun-blocking agents in seawater of beaches and coral reefs of Okinawa Island, Japan. Mar Pollut Bull 77:333-340. https://doi.org/10.1016/j.marpolbul.2013.09.013

13. Fent K, Zenker A, Rapp M (2010) Widespread occurrence of estrogenic UV-filters in aquatic ecosystems in Switzerland. Environ Pollut 158:18171824. https://doi.org/10.1016/j.envpol.2009.11.005

14. Nečasová K, Bányiová J, Literák PČ (2016) New probabilistic risk assessment of ethylhexyl methoxycinnamate: comparing the genotoxic effects of trans- and cis-EHMC. Environ Toxicol 32:569-580. https://doi. org/10.1002/tox.22260

15. Kunz PY, Fent K (2006) Multiple hormonal activities of UV filters and comparison of in vivo and in vitro estrogenic activity of ethyl-4-aminobenzoate in fish. Aquat Toxicol 79:305-324. https://doi.org/10.1016/j. aquatox.2006.06.016 
16. Klammer H, Schlecht C, Wuttke W, Jarry H (2005) Multi-organic risk assessment of estrogenic properties of octyl-methoxycinnamate in vivo: a 5-day sub-acute pharmacodynamic study with ovariectomized rats. Toxicology 215:90-96. https://doi.org/10.1016/j.tox.2005.06.026

17. Schlumpf M, Cotton B, Conscience M, Haller V, Steinmann B, Lichtensteiger W (2001) Environ Health Perspect 109:239-244. https://doi. org/10.1289/ehp.01109239

18. Christen V, Zucchi S, Fent K (2011) Effects of the UV-filter 2-ethyl-hexyl4-trimethoxycinnamate (EHMC) on expression of genes involved in hormonal pathways in fathead minnows (Pimephales promelas) and link to vitellogenin induction and histology. Aquat Toxicol 102:167-176. https ://doi.org/10.1016/j.aquatox.2011.01.013

19. Inui M, Adachi T, Takenaka S, Inui H, Nakazawa M, Ueda M, Watanabe H, Mori C, Iguchi T, Miyatake K (2003) Effect of UV screens and preservatives on vitellogenin and choriogenin production in male medaka (Oryzias latipes). Toxicology 194:43-50. https://doi.org/10.1016/S0300 $-483 \times(03) 00340-8$

20. Zucchi S, Oggier DM, Fent K (2011) Global gene expression profile induced by the UV-filter 2-ethyl-hexyl-4-trimethoxycinnamate (EHMC) in zebrafish (Danio rerio). Environ Pollut 159:3086-3096. https://doi. org/10.1016/j.envpol.2011.04.013

21. Boas M, Feldt-Rasmussen U, Skakkebæk NE, Main KM (2006) Environmental chemicals and thyroid function. Eur J Endocrinol 154:599-611. https:// doi.org/10.1530/eje.1.02128

22. Klammer H, Schlecht C, Wuttke W, Schmutzler C, Gotthardt I, Koehrle J, Jarry H (2007) Effects of a 5-day treatment with the UV-filter octyl-methoxycinnamate (OMC) on the function of the hypothalamo-pituitary-thyroid function in rats. Toxicology 238:192-199. https://doi.org/10.1016/j. tox.2007.06.088

23. Seidlová-Wuttke D, Christoffel J, Rimoldi G, Jarry H, Wuttke W (2006) Comparison of effects of estradiol with those of octylmethoxycinnamate and 4-methylbenzylidene camphor on fat tissue, lipids and pituitary hormones. Toxicol Appl Pharmacol 214:1-7. https://doi.org/10.1016/j. taap.2005.11.002

24. Axelstad M, Boberg J, Hougaard KS, Christiansen S, Jacobsen PR, Mandrup KR, Nellemann C, Lund SP, Hass U (2011) Effects of pre- and postnatal exposure to the UV-filter octyl methoxycinnamate (OMC) on the reproductive, auditory and neurological development of rat offspring. Toxicol Appl Pharmacol 250:278-290. https://doi.org/10.1016/j.taap.2010.10.031

25. Lee I, Lee J, Jung D, Kim S, Choi K (2019) Two-generation exposure to 2-ethylhexyl 4-methoxycinnamate (EHMC) in Japanese medaka (Oryzias latipes) and its reproduction and endocrine related effects. Chemosphere 228:478-484. https://doi.org/10.1016/j.chemosphere.2019.04.123

26. ECHA (European Chemicals Agency) (2012). CoRAP (Community Rolling Action Plan) 2012-2014. https://echa.europa.eu/documents/10162 /13628/corap_2012_en.pdf/0f6967f5-b6b3-484b-896f-32bfb3598ba9

27. ECHA (European Chemicals Agency) (2013) Justification for the selection of a candicate CoRAP substance - 2-Ethylhexyl 4-methoxycinnamate. https://echa.europa.eu/documents/10162/5d8d8771-0175-130a-098eb72d1ec8e4aa

28. EC (European Commission) (2015) European Commission Implementation Decision 2015/495/EC establishing a watch list of substances for Union-wide monitoring in the field of water policy pursuant to Directive 2008/105/EC of the European Parliament and of the Council. OJ L 78/40 https://eur-lex.europa.eu/legal-content/EN/TXT/PDF/?uri=CELEX:32015 D0495\&rid $=1$

29. EC (European Commission) (2018) Commission Implementing Decision (EU) 2018/840 of 5 June 2018 establishing a watch list of substances for Union-wide monitoring in the field of water policy pursuant to Directive 2008/105/EC of the European Parliament and of the Council and repealing Commission Implementing Decision (EU) 2015/495 (notified under document C(2018) 3362). https://eur-lex.europa.eu/eli/ dec_impl/2018/840/oj

30. Gomez Cortes L, Marinov D, Sanseverino I, Navarro Cuenca A, Niegowska M, Porcel Rodriguez E, Lettieri T (2020) Selection of substances for the 3rd Watch List under the Water Framework Directive, EUR 30297 EN Luxembourg, Publications Office of the European Union, ISBN 978-92-7619426-2. https://ec.europa.eu/jrc/en/publication/selection-substances -3rd-watch-list-under-water-framework-directive

31. Nagorka R, Koschorreck J (2020) Trends for plasticizers in German freshwater environments - evidence for the substitution of DEHP with emerging phthalate and non-phthalate alternatives. Environ Pollut 262:114237. https://doi.org/10.1016/j.envpol.2020.114237

32. ESB (German Environmental Specimen Bank) (2020a). https://www. umweltprobenbank.de/en/documents/profiles/sampling_areas

33. Fliedner A, Lohmann N, Rüdel H, Teubner D, Wellmitz J, Koschorreck J (2016) Current levels and trends of selected EU Water Framework Directive priority substances in freshwater fish from the German environmental specimen bank. Environ Pollut 216: 866-876. https://www.sciencedir ect.com/science/article/pii/S0269749116305486

34. ESB (German Environmental Specimen Bank) (2020b) Suspended particulate matter. https://www.umweltprobenbank.de/en/documents/profiles/ specimen_types/14940

35. Fryer RJ, Nicholson MD (1999) Using smoothers for comprehensive assessments of contaminant time series in marine biota. ICES J Mar Sci 56:779-790. https://doi.org/10.1006/jmsc.1999.0499

36. FOEN (Federal Office for the Environment) - Hydrological data and forecasts (2020) Basel - Water discharge. https://www.hydrodaten.admin ch/en/2289.html

37. StEB Köln (2020) Information website. https://www.steb-koeln.de/hochw asser-und-ueberflutungsschutz/akutes-hochwasser/der-koelner-pegel/ der-koelner-pegel.jsp

38. Drewes JE, Karakurt S, Schmid L, Bachmaier M, Hübner U, Clausnitzer V, Timmermann R, Schätzl P, McCurdy S (2018) Dynamik der Klarwasseranteile in Oberflächengewässern und mögliche Herausforderungen für die Trinkwassergewinnung in Deutschland (in German). Federal Environment Agency (publisher) 59/2018. https://www.umweltbundesamt.de/ publikationen/dynamik-der-klarwasseranteile-in

39. WSV (2020) Pegel Online-information website. https://www.pegelonlin e.wsv.de/gast/stammdaten?pegelnr $=26400550$

40. Li W, Ma Y, Guo C, Hu W, Liu K, Wang Y, Zhu T (2007) Occurrence and behavior of four of the most sunscreen UV filters in a wastewater reclamation plant. Water Res 41:3506-3512. https://doi.org/10.1016/j.watre s.2007.05.039

41. Balmer ME, Buser HR, Müller MD, Poiger T (2004) Occurrence of the Organic UV Filter Compounds BP-3, 4-MBC, EHMC, and OC. BUWAL Project: 3189.041.01.14. https://www.agroscope.admin.ch/agroscope/ de/home/publikationen/suchen/_jcr_content/par/externalcontent.exter nal.exturl.pdf/aHROcHM6Ly9pcmEuYWdyb3Njb3BILmNoL2ZyLUNILOFqY XgvRW/luemVscHVibGIrYXRpb24vRG93bmxvYWQ_ZWluemVscHVibGlr/ YXRpb25JZD0xNDc3.pdf

42. Martins Ferreira Miranda de Távaro J (2014) Presence and environmental impact of personal-care products (UV filters) in urban aquatic ecosystems. Tesis de master, Escola de Camins PPC/ Barcelona School of Civil Engineering_Universitat Politécnica De Catalunya. http://hdl.handl e.net/2099.1/22722

43. Hopkins ZR, Blaney L (2016) An aggregate analysis of personal care products in the environment: identifying and distribution of environmentally-relevant concentrations. Environ Int 92-93:301-316. https://doi. org/10.1016/j.envint.2016.04.026

44. Ekpeghere KI, Kim U-J, O S-H, Kim H-Y, Oh J-E, (2016) Distribution and seasonal occurrence of UV filters in rivers and wastewater treatment plants in Korea. Sci Total Environ 542:121-128. https://doi.org/10.1016/j. scitotenv.2015.10.033

45. Krzeminski P, Schwermer C, Wennberg A, Langford K, Vogelsang C (2017) Occurrence of UV filters, fragrances and organophosphate flame retardants in municipal WWTP effluents and their removal during posttreatment. J Hazard Mater 323:166-176. https://doi.org/10.1016/j.jhazm at.2016.08.001

46. Remberger M, Bibi M, Kaj L, Brorström-Lundén E (2015) Screening 2014 Analysis of UV-filters (and fragrances) used in cosmetics and textiles. IVL Swedish Environmental Research Institute. http://www.diva-portal.org/ smash/get/diva2:932530/FULLTEXT01.pdf

47. Pintado-Herrera MG, Combi T, Corada-Fernández C, González-Mazo E, Lara-Martín PA (2017) Occurrence and spatial distribution of legacy and emerging organic pollutants in marine sediments from the Atlantic coast (Andalusia, SW Spain). Sci Total Environ 605-606:980-994. https://doi. org/10.1016/j.scitotenv.2017.06.055

48. Rodil R, Moeder M (2008) Development of a simultaneous pressurisedliquid extraction and clean-up procedure for the determination of UV filters in sediment. Anal Chim Acta 612:152-159. https://doi.org/10.1016/j. aca.2008.02.030 
49. Gago-Ferrero P, Díaz-Cruz MS, Barceló D (2011) Fast pressurized liquid extraction with in-cell purification and analysis by liquid chromatography tandem mass spectrometry for the determination of UV filters and their degradation products in sediments. Anal Bioanal Chem 400:2195-2204. https://doi.org/10.1007/s00216-011-4951-1

50. Pinto-Herrera MG, González-Mazo E, Lara-Martín PA (2016) In-cell cleanup pressurized liquid extraction and gaschromatography-tandem mass spectrometry determination of hydrophobic persistent and emerging organic pollutants in coastal sediments. J Chromatogr A 1429:107-118. https://doi.org/10.1016/j.chroma.2015.12.040

51. Thomas KV, Schlabach M, Langford K, Fjeld E, Øxnevad S, Rundberget T, Bæk K, Rostowski PM, Harju M (2014) NIVA and NILU Screening program 2013 - New bisphenols, organic peroxides, fluorinated siloxanes, organic UV filters and selected PBT substances. Norwegian Environment Agency Report M-176/2014. https://niva.brage.unit.no/niva-xmlui/handle/11250 $/ 277277$

52. Combi T, Pintado-Herrera MG, Lara-Martín PA, Miserocchi S, Langone L, Guerra R (2016) Distribution and fate of legacy and emerging contaminants along the Adriatic Sea: a comparative study. Environ Pollut 218:1055-1064. https://doi.org/10.1016/j.envpol.2016.08.057

53. Díaz-Cruz MS, Molins-Delgado D, Serra-Roig MP, Kalogianni E, Skoulikidis N Th, Barceló D (2019) Personal care products reconnaissance in EVROTAS river (Greece): water-sediment partition and bioaccumulation in fish. Sci Total Environ 651:3079-3089. https://doi.org/10.1016/j.scito tenv.2018.10.008

54. Mandaric L, Diamantini E, Stella E, Cano-Paoli K, Valle-Sistac J, Molins-Delgado D, Bellin A, Chiogna G, Majone B, Diaz-Cruz MS, Sabater S, Barcelo D, Petrovic M (2017) Contamination sources and distribution patterns of pharmaceuticals and personal care products in Alpine rivers strongly affected by tourism. Sci Total Environ 590-591:484-494. https://doi. org/10.1016/j.scitotenv.2017.02.185

55. Apel C, Joerss H, Ebinghaus R (2018) Environmental occurrence and hazard of organic UV stabilizers and UV filters in the sediment of European North and Baltic Seas. Chemosphere 212:254-261. https://doi. org/10.1016/j.chemosphere.2018.08.105

56. Rastogi SC (2002) UV filters in sunscreens-a survey. Contact Dermatitis 46(6):348-351. https://doi.org/10.1034/j.1600-0536.2002.460605.x

57. Manová E, von Goetz N, Hauri U, Bogdal C, Hungerbühler K (2013) Organic UV filters in personal care products in Switzerland: a survey of occurrence and concentrations. Int J Hyg Environ Health 216:508-514. https://doi.org/10.1016/j.ijheh.2012.08.003

58. Stiefel C, Schwack W (2015) Photoprotection in changing times - UV filter efficacy and safety, sensitization processes and regulatory aspects. Int J Cosmet Sci 37:2-30. https://doi.org/10.1111/ics.12165
59. Danish EPA (Environmental Protection Agency) (2015) Survey and health assessment of UV filters - Survey of chemical substances in consumer products No. 142. https://mst.dk/service/publikationer/publikationsark iv/2015/okt/survey-and-health-assessment-of-uv-filters/

60. BVL (Federal Office of Consumer Protection and Food Safety) (2016) BVL Report 12.4 (in German). https://www.bvl.bund.de/SharedDocs/Downl oads/01_Lebensmittel/01_Im_mon_dokumente/01_Monitoring_Beric hte/2016_Im_monitoring_bericht.pdf;jsessionid=E29FA84D01876F2 1508323DEC3074D4D.1_cid369? _blob=publicationFile $\& \mathrm{v}=8$

61. Labille J, Slomberg D, Catalano R, Robert S, Apers-Tremelo ML, Boudenne JL, Manasfi T, Radakovitch O (2020) Assessing UV filters input into beach waters during recreational activity: a field study of three Mediterranean beaches from consumer survey to water analysis. Sci Total Environ 706:136010. https://doi.org/10.1016/j.scitotenv.2019.136010

62. Osterwalder U, Hareng L (2016) Global UV filters: current technologies and future innovations. In: Lim HW, Wang SQ (eds) Principles and practice of photoprotection. Adis, Cham. https://doi.org/10.1007/978-3-31929382-0_11

63. Fourtanier A, Moyal D, Seite S (2012) UVA filters in sun-protection products: regulatory and biological aspects. Photochem Photobiol Sci 11:81-89. https://doi.org/10.1039/c1pp05152k

64. Carvalho RN, Ceriani L, Ippolito A, Lettieri T (2015) Development of the first Watch List under the Environmental Quality Standards Directive. EUR 2714, Publications Office of the European Union, Luxembourg. https:// doi.org/10.2788/101376. http://publications.europa.eu/resource/cella r/9de9391e-914a-41a1-a6fe-c223507785be.0001.01/DOC_1

65. ECHA (European Chemicals Agency) (2018) Decision on substance evaluation - 2-Ethylhexyl trans-4-methoxycinnamate (OMC). https://echa. europa.eu/documents/10162/88e0cc0b-d64c-1b9e-d706-61c0cce731da

66. Schneider SL, Lim HW (2019) A review of inorganic UV filters zinc oxide and titanium dioxide. Photodermatol Photoimmunol Photomed 35(6):442-446. https://doi.org/10.1111/phpp.12439

67. Fagervold SK, Rodrigues AS, Rohée C, Roe R, Bourrain M, Stien D, Lebaron P (2019) Occurrence and environmental distribution of 5 UV filters during the summer season in different water bodies. Water Air Soil Pollut 230:172. https://doi.org/10.1007/s11270-019-4217-7

68. BASF (2019) BASF pushes UV filter production capacities. Press release. https://www.basf.com/global/en/media/news-relea ses/2019/12/p-19-422.html

\section{Publisher's Note}

Springer Nature remains neutral with regard to jurisdictional claims in published maps and institutional affiliations.

\section{Submit your manuscript to a SpringerOpen ${ }^{\odot}$ journal and benefit from:}

- Convenient online submission

- Rigorous peer review

- Open access: articles freely available online

- High visibility within the field

Retaining the copyright to your article

Submit your next manuscript at $\boldsymbol{\nabla}$ springeropen.com 